\title{
Extracranial and intracranial vertebrobasilar dissections: diagnosis and prognosis
}

\author{
J M de Bray, I Penisson-Besnier, F Dubas, J Emile
}

Vascular investigations laboratory J M de Bray

Department of
Neurology A
I Penisson-Besnier
F Dubas
Department of
Neurology B, CHU
Angers, 49033 France
J Emile
Correspondence to:
Dr J M de Bray, Explorations
Fonctionnelles Vasculaires,
CHU Angers, 49033,
France.
Received 30 April 1996 and
in final revised form 18
February 1997
Accepted 3 March 1997

\begin{abstract}
Objectives-To compare the diagnosis and prognosis of extracranial versus intracranial vertebral artery dissections without intracerebral haemorrhage.

Methods-Twenty two vertebral artery dissections were defined by intra-arterial angiography and classified in two groups: group 1, nine extracranial dissections (seven patients) and group 2, 13 intracranial dissections (nine patients), involving the basilar artery in five cases. Bilateral dissections were found in $38 \%$ of the population. Before angiography, all the patients had been investigated by continuous wave Doppler, colour coded Doppler, and transcranial Doppler. Mean follow up was 44 months.

Results-The two most important symptoms of both dissections ( $81 \%$ of patients) were unbearable pain preceding stroke and progressive onset of stroke within a few hours. Severe ultrasonic abnormalities were present in $94 \%$ of the patients whereas specific ultrasonic signs (segmental dilation with eccentric channel) were rare $(19 \%)$ in both groups. Major strokes and brainstem strokes represented respectively $67 \%$ and $78 \%$ in intracranial versus $43 \%$ and $29 \%$ in extracranial dissections. Severe sequelae (permanent disabling motor or cerebellar deficit) were more often associated with intracranial (44\%) than with extracranial dissections $(14 \%)$. No recurrence of dissection and no cerebral haemorrhage were found under heparin. Significant factors of poor outcome $(P<0.05)$ were the initial severity of the stroke and the bilateral location of dissections.

Conclusion-The combination of a pain and a progressive onset of the stroke, corroborated by ultrasonic findings, could have helped to recognise most of these types of dissections. Intracranial dissections have a poorer prognosis than extracranial dissections.
\end{abstract}

(F Neurol Neurosurg Psychiatry 1997;63:46-51)

Keywords: dissections; vertebral arteries; ultrasound; follow up

The prevalence of vertebral artery dissections is not precisely known ${ }^{1-8}$ because these lesions can be difficult to diagnose on an angiography using at least two planes, especially when they cause an occlusion or if the vessel has a small internal diameter.

Extracranial dissections, ${ }^{4-7}$ often due to an haematoma within the media or the intima, would have a benign prognosis, whereas intracranial dissections originating from the intradural segment and giving subadventitial haematoma often extending to the basilar artery, ${ }^{8-14}$ are reported as entailing severe subarachnoid haemorrhage, brainstem strokes, or persistent pseudoaneurysms. Nevertheless, recent studies indicate that non-ruptured intracranial vertebral artery dissections could have a benign nature and be medically treated. ${ }^{12-14}$ Because follow up was long term in only one series ${ }^{4}$ and prognosis of dissections is controversial, we report a prospective study of 22 consecutive vertebral artery dissections studied by ultrasonic methods, diagnosed by angiography, and followed up for an average of 44 months.

Our purpose was to compare the clinical and ultrasonic findings and the prognosis of extracranial versus intracranial vertebral artery dissections.

\section{Material and methods}

All vertebral artery dissections investigated by ultrasonic methods, then defined by intraarterial angiography were included in this survey. Sixteen consecutive patients (nine women, seven men), mean age 41 (SD 12) were admitted over a seven year period (1988-1995). Table 1 and table 2 summarise the clinical data. The mean clinical and ultrasonic follow up was 44 (SD 2) months.

Diagnosis of vertebral artery dissection was carried out using digital intra-arterial angiography (Siemens Digitron or General Electric Company devices) and performed by selective femoral catheterisation with two orthogonal planes. Two groups were defined according to the proximal site of the dissection: group 1, extracranial vertebral artery dissections originating from the extradural segment (seven patients, nine dissections) and group 2, intracranial vertebral artery dissections originating from the intradural segment (nine patients, 13 dissections). Patients with bilateral dissections involving the intradural segment of one vertebral artery were included in group 2 (patients $8,9,10)$. All patients had CT or MRI. The time delay between the first ischaemic symptom and the angiography was always defined as a dissection can be recanalised within a week.

Continuous wave Doppler was performed as previously described ${ }^{75}$ and the extracranial 
Table 1 Clinical findings in extracranial vertebral artery dissections (seven patients)

\begin{tabular}{|c|c|c|c|c|c|c|c|c|}
\hline $\begin{array}{l}\text { Patient/ } \\
\text { sex/age }\end{array}$ & $\begin{array}{l}\text { Vascular risk } \\
\text { factors }\end{array}$ & Preceding "trauma" & $\begin{array}{l}\text { Location of the } \\
\text { pain/side }\end{array}$ & $\begin{array}{l}\text { Onset of } \\
\text { symptoms }\end{array}$ & Neurological signs & $\begin{array}{l}\text { Treatment } \\
\text { duration }\end{array}$ & Sequelae & $\begin{array}{l}\text { Follow } \\
\text { up }(y)\end{array}$ \\
\hline $1 / \mathrm{M} / 51$ & None & $\begin{array}{l}\text { Dubious (minor } \\
\text { head injury } 28 \\
\text { days before } \\
\text { stroke) }\end{array}$ & Neck/L & Acute & $\begin{array}{l}\text { Vestibular } \\
\text { syndrome (ms) }\end{array}$ & None & 0 & 5 \\
\hline $2 / \mathrm{F} / 30$ & $\begin{array}{l}\text { Right carotid } \\
\text { artery dissection } \\
10 \text { years before }\end{array}$ & None & $\begin{array}{l}\text { Anterior } \\
\text { head }\end{array}$ & Progressive & $\begin{array}{l}\text { Medial } \\
\text { medullary } \\
\text { syndrome (MS) }\end{array}$ & $\begin{array}{l}\text { Ac } 8 \\
\text { days }\end{array}$ & 0 & 6 \\
\hline $3 / \mathrm{F} / 34$ & Smoking & $\begin{array}{l}\text { Neck } \\
\text { manipulation the } \\
\text { day of stroke }\end{array}$ & $\mathrm{Neck} / \mathrm{L}$ & Acute & $\begin{array}{l}\text { VBTIA (vertigo, } \\
\text { right IV) }\end{array}$ & $\begin{array}{l}\text { Ac } 90 \\
\text { days }\end{array}$ & $\begin{array}{l}\text { Vertigo; no } \\
\text { sign }\end{array}$ & 4 \\
\hline $4 / \mathrm{M} / 41$ & None & None & Neck/R & Progressive & $\begin{array}{l}\text { Pontomedullar } \\
\text { syndrome (MS) }\end{array}$ & $\begin{array}{l}\text { Ac } 90 \\
\text { days }\end{array}$ & $\begin{array}{l}\text { Hemiplegia; } \\
\text { dysarthria; } \\
\text { cerebellar } \\
\text { syndrome }\end{array}$ & 1 \\
\hline $5 / F / 64$ & Hypertension & $\begin{array}{l}\text { Minor head injury } \\
2 \text { days before } \\
\text { stroke }\end{array}$ & $\begin{array}{l}\text { Neck/R } \\
\text { occiput }\end{array}$ & Acute & $\begin{array}{l}\text { Occipital } \\
\text { syndrome (ms) }\end{array}$ & Ap & 0 & 4 \\
\hline $6 / \mathrm{M} / 42$ & None & None & None & Acute & $\begin{array}{l}\text { Vestibular } \\
\text { syndrome }(\mathrm{ms}) \\
\text { due to a right } \\
\text { cerebellar } \\
\text { (PICA) infarct }\end{array}$ & Ap & 0 & 0.5 \\
\hline $7 / \mathrm{M} / 56$ & None & None & None & Progressive & $\begin{array}{l}\text { Left cerebellar } \\
\text { syndrome (MS) }\end{array}$ & $\begin{array}{l}\text { Ac } 10 \\
\text { days }\end{array}$ & 0 & 5 \\
\hline
\end{tabular}

$\mathrm{OC}=\mathrm{Oral}$ contraceptives; $\mathrm{ms}=$ minor stroke; $\mathrm{MS}=$ major stroke; VBTIA=vertebrobasilar transient ischaemic attack; $\mathrm{Ac}=$ anticoagulant; $\mathrm{Ap}=$ antiplatelet drug; $\mathrm{L}=\mathrm{left} ; \mathrm{R}=$ right.

proximal and distal segments of the vertebral artery were recorded in each patient. The continuous wave Doppler device was an Angiodine (DMS French Company) using a $4 \mathrm{MHz}$ probe or a Transpect (MEDASONICS American company) using a $5 \mathrm{MHz}$ probe and a spectrum analyser. Maximal systolic and diastolic blood flow velocities (BFVs) were recorded for each vessel and the resistive index (RI) was calculated according to the formula: BFV.

$\mathrm{RI}=$ systolic $\mathrm{BFV}$ - diastolic $\mathrm{BFV} /$ systolic

Duplex scanning ${ }^{7}{ }^{15}$ was performed using a high resolution real time colour coded duplex Doppler device 128 X P (Acuson Company, USA) with a $7 \mathrm{MHz}$ linear probe and a $7 \mathrm{MHz}$ sectorial probe. The extracranial carotid arteries and the intertransverse and proximal vertebral artery were imaged on both sides and pulsed Doppler velocities were recorded.

Transcranial pulsed Doppler sonography was performed with the same continuous wave Doppler device which was combined with a pulsed Doppler using a $2 \mathrm{MHz}$ carrying probe. The methodology has been previously described. ${ }^{17-19}$ All the main cerebral arteries

Table 2 Ultrasonic and angiographic findings. Follow up in extracranial vertebral artery dissections (11 lesions)

\begin{tabular}{lllll}
\hline Patients/sex & $\begin{array}{l}\text { Ultrasonic } \\
\text { lesions }\end{array}$ & Angiographic lesions & $\begin{array}{l}\text { Delay between stroke } \\
\text { and angiography } \\
\text { (days) }\end{array}$ & Recanalisation \\
\hline $1 / \mathrm{M}$ & LV3 oc & LV2V3st & 6 months & + \\
$2 / \mathrm{F}$ & R low flow & RV1V3 irregular & 2 days & + \\
& V1V3 & LV3 st (dl) & 20 days & 0 \\
$3 / \mathrm{F}$ & LV3st, dl & V2 FMD & & (FMD) \\
& L low flow & LV0 st (dl) & 30 days & 0 \\
$4 / \mathrm{M}$ & V0V3 & RV1 st & & 0 \\
& RV0st, d1 & LVO oc & 9 months & + \\
$5 / \mathrm{F}$ & LV4 oc & L50\% V2V3 st & 20 days & + \\
$6 / \mathrm{M}$ & Ltortuous & RV4 FMD & 13 days & (FMD) \\
& V2 as RV2 & LVO oc & & 0 \\
$7 / \mathrm{M}$ & LV3 oc & RV3 st & & 0
\end{tabular}

VA=Vertebral artery; $\mathrm{BA}=$ basilar artery; $\mathrm{FMD}=$ fibromuscular dysplasia; $\mathrm{L}=\mathrm{left}$; $\mathrm{R}=$ right; $\mathrm{oc}=\mathrm{occlusion} ; \mathrm{dl}=$ dilation; $\mathrm{Ap}=$ antiplatelet drug; $\mathrm{Ac}=$ anticoagulant. were identified at different depths, particularly the intracranial vertebral arteries and the basilar artery which was always recorded at a depth of $85 \mathrm{~mm}$ or more.

\section{ULTRASONIC DIAGNOSTIC CRITERIA OF}

OBSTRUCTIVE LESIONS

The vertebral artery was identified in its intertransverse segment by Duplex scanning and its calibre was measured. The blood flow velocities were recorded with a corrected angle $<60^{\circ}$ on the pulsed Doppler gate taking into account the course of the vessel. Segmental dilation, more easily recognised by the colour coded Doppler, was searched for $^{20}$ as well as an eccentric channel in the proximal or distal part of the artery. The criterion for proximal vertebral artery occlusion was an absence of BFV in the intertransverse segment. Distal occlusion was marked by an isolated systolic BFV or a bidirectional sharp systolic BFV without continuous diastolic component in the intertransverse segment of the vertebral artery. Moderate stenosis showed a segmental increase of velocity whereas a tight stenosis $(75 \%$ or more) showed a similar pattern with positive and negative low frequencies of high energy. Severely reduced vertebral artery BFVs contrasting with a $>2 \mathrm{~mm}$ diameter of the vertebral artery were noted.

FOLLOW UP

All patients were examined every year and studied by ultrasonic methods using the same methodology. A control angiography was performed in one patient.

Statistical analysis was performed using $\chi^{2}$ and Fisher's tests. Permanent deficits with disability defined by a $<3$ Rankin scale score, were compared with the following indices: initial severity of the strokes defined by a $<10$ Canadian neurological scale score, sites of dissections, bilateral location of lesions extending to the basilar artery, fibromuscular dysplasia, 


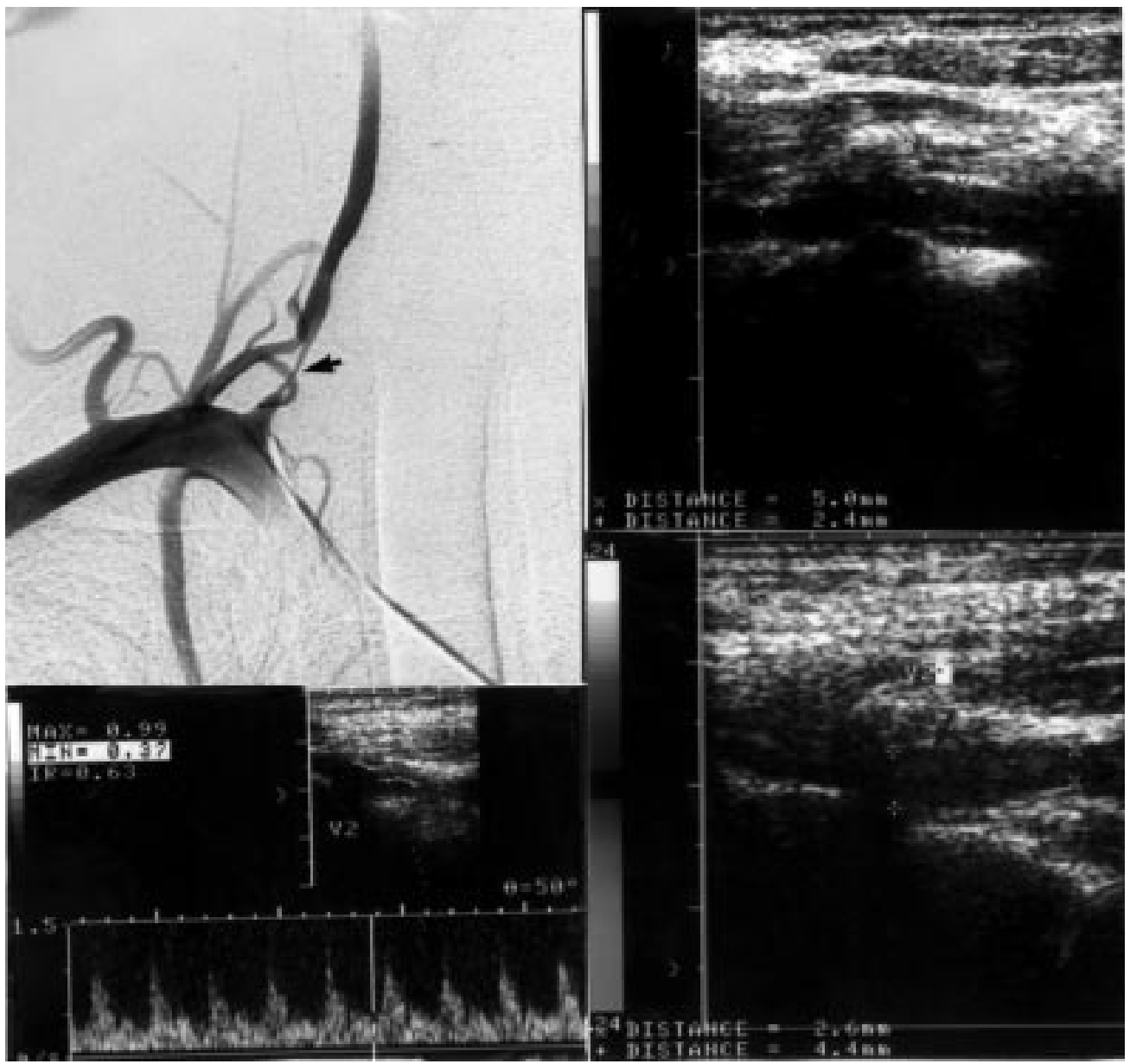

Figure 1 Patient 4: pontomedullary syndrome due to a spontaneous extracranial vertebral artery dissection. Duplex scanning and colour pulsed Doppler. Suggestive sign $=$ a segmental dilatation of the pretransverse part of the vertebral artery, in B mode with an eccentric channel and an increase of blood flow velocities. Angiography shows a segmental eccentric channel in the pretransverse part of the vertebral artery.

resolution of dissections, and anticoagulant treatment.

\section{Results}

EXTRACRANIAL DISSECTIONS

Clinical data

This group (table 1) included seven patients and a total of nine dissections. They predominantly occurred in young and middle aged adults (mean age 40). Two patients had one or more vascular risk factors, none had a history of common migraine. One had experienced a carotid artery dissection 10 years earlier without an angiographic aspect of fibromuscular dysplasia.

Vertebral artery dissection was spontaneous in four patients, occurred after a neck manipulation in one, and after a minor neck injury in another. In one patient the relation with trauma was dubious because it happened four weeks before the stroke.

Occipital headache, or neck pain (not always ipsilateral to the dissection), or both were initially present in five patients. The onset of the stroke was progressive (few hours) in three patients. Vertebrobasilar transient ischaemic attacks were seen in one patient. Major strokes occurred in $43 \%$ of patients and brainstem strokes in $29 \%$. Two cerebellar strokes were found.

\section{Ultrasonic data}

Haemodynamic abnormalities (table 2) were found in all but one patient. Suggestive signs such as a segmental dilatation combined with an eccentric residual channel visualised by Duplex scanning were detected once in the pretransverse segment (V1, fig 1) and once in the atlantoaxial segment (V3), and assessed by angiography. Two false negatives (22\%) were noted in extracranial dissections, giving a $78 \%$ sensitivity.

\section{Angiographic data}

A fibromuscular dysplasia defined by a "string of beads" was found in two patients. One had a bilateral dissection and one a middle cerebral artery intracranial aneurysm measuring $3 \mathrm{~mm}$. The two oldest patients had a $>50 \%$ carotid stenosis.

Follow up and treatment

After a CT showing no cerebral bleeding, two patients were treated with anticoagulants (heparin) within the first five days. Three 
Table 3 Clinical findings in intracranial vertebral artery dissections (nine patients)

\begin{tabular}{|c|c|c|c|c|c|c|c|c|}
\hline $\begin{array}{l}\text { Patient/sex/ } \\
\text { age }\end{array}$ & Vascular risk factors & $\begin{array}{l}\text { Preceding, } \\
\text { "trauma" }\end{array}$ & $\begin{array}{l}\text { Location of the } \\
\text { pain/side }\end{array}$ & $\begin{array}{l}\text { Onset of } \\
\text { symptoms }\end{array}$ & Neurological signs & $\begin{array}{l}\text { Treatment } \\
\text { duration }\end{array}$ & Sequelae & $\begin{array}{l}\text { Follow up } \\
\text { (y) }\end{array}$ \\
\hline $8 / \mathrm{F} / 21$ & Current user of OC & $\begin{array}{l}\text { Minor head } \\
\text { injury } 3 \text { days } \\
\text { before stroke }\end{array}$ & Neck; occiput & Progressive & $\begin{array}{l}\text { Pons syndrome } \\
\text { (MS) }\end{array}$ & Ac 180 days & Ataxia; paraparesia & 0.5 \\
\hline $9 / \mathrm{F} / 21$ & Current user of OC & $\begin{array}{l}\text { Neck trauma } \\
\text { (drowning) } 5 \\
\text { days before } \\
\text { stroke }\end{array}$ & None & Progressive & $\begin{array}{l}\text { Medial } \\
\text { midpontine } \\
\text { syndrome (MS) } \\
\text { preceded by a } \\
\text { VBTIA (vertigo, } \\
\text { ataxia) }\end{array}$ & Ac 21 days & $\begin{array}{l}\text { Hemiparesia; } \\
\text { dysarthria }\end{array}$ & 6 \\
\hline $10 / F / 34$ & None & $\begin{array}{l}\text { Neck } \\
\text { manipulation } 1 \\
\text { day before } \\
\text { stroke }\end{array}$ & Neck/R & Progressive & $\begin{array}{l}\text { Wallenberg's } \\
\text { syndrome (MS) }\end{array}$ & Ac 15 days & $\begin{array}{l}\text { Nystagmus; } \\
\text { dysarthria; sensory } \\
\text { syndrome }\end{array}$ & 6 \\
\hline $11 / \mathrm{M} / 43$ & $\begin{array}{l}\text { Smoking; lower limb } \\
\text { ischaemia; angina }\end{array}$ & $\begin{array}{l}\text { Neck trauma } 1 \\
\text { day before } \\
\text { stroke }\end{array}$ & None & Acute & $\begin{array}{l}\text { Upper brainstem } \\
\text { syndrome (MS) }\end{array}$ & Ac 30 days & 0 & 3 \\
\hline $12 / \mathrm{F} / 41$ & Migraine & None & Occiput & Acute & $\begin{array}{l}\text { None; nausea, } \\
\text { vomiting }\end{array}$ & - & 0 & 6 \\
\hline $13 / \mathrm{M} / 45$ & None & None & Neck & Acute & $\begin{array}{l}\text { Wallenberg's } \\
\text { syndrome (MS) }\end{array}$ & Ac 30 days & 0 & 0.5 \\
\hline $14 / \mathrm{M} / 41$ & $\begin{array}{l}\text { Smoking; } \\
\text { hypercholesterolaemia; } \\
\text { migraine }\end{array}$ & None & Posterior neck & Progressive & $\begin{array}{l}\text { Pontomedullar } \\
\text { syndrome (MS) }\end{array}$ & Ac 25 days & Ataxia & 4.5 \\
\hline $15 / \mathrm{F} / 47$ & Migraine & None & Occiput & Acute & $\begin{array}{l}\text { Upper brainstem } \\
\text { syndrome (ms) }\end{array}$ & - & 0 & 5.5 \\
\hline $16 / \mathrm{F} / 51$ & Hypercholesterolaemia & None & None & Acute & $\begin{array}{l}\text { Vestibular } \\
\text { syndrome (ms) }\end{array}$ & - & Vertigo; no sign & \\
\hline
\end{tabular}

months after the stroke, six patients were treated by antiplatelet drugs and one had no treatment. Two patients had sequelae but only one maintained a disabling motor and cerebellar deficit. Neither recurrent stroke nor transient ischaemic attack were found whereas there were four ultrasonic resolutions of dissections. One occlusion among three was recanalised.

INTRACRANIAL DISSECTIONS

Clinical data

During a seven year period, we found nine patients with 13 intracranial vertebral artery dissections (table 3 ).

The mean age ( 8 years) of these patients was slighty less than group 1 . Five patients had one or more vascular risk factors. Three patients had common migraine. The vertebral artery dissection occurred after a neck manipulation in one and there was a closely temporal related history of minor head or neck injury in three. Occipital or neck pain was present in six patients with a progressive onset of the stroke within few hours in four patients. One patient described an intracranial pulsatile bruit and presented with symptoms of subarachnoid haemorrhage which was not confirmed by CT and lumbar puncture. Vertebral transient ischaemic attacks were exceptional (one patient). Major strokes and brainstem strokes represented respectively $67 \%$ and $78 \%$ of patients. Isolated Wallenberg's syndrome (two patients) occurred only in this group. A patient admitted for a lower limb ischaemia, three years after his dissection, died suddenly.

ULTRASONIC DATA

Haemodynamic abnormalities were found in all patients (table 4, fig 2). A suggestive sign of dissection was located once in the atlantoaxial segment(V3) in a patient with contralateral intracranial vertebral artery dissections. Five false
Table 4 Ultrasonic and angiographic findings. Follow up in intracranial vertebral artery dissections (18 lesions)

\begin{tabular}{|c|c|c|c|c|}
\hline $\begin{array}{l}\text { Patients/ } \\
\text { sex }\end{array}$ & $\begin{array}{l}\text { Ultrasonic } \\
\text { lesions }\end{array}$ & $\begin{array}{l}\text { Angiography } \\
\text { lesions }\end{array}$ & $\begin{array}{l}\text { Delay } \\
\text { between } \\
\text { stroke and } \\
\text { angiography } \\
\text { (days) }\end{array}$ & Recanalisation \\
\hline \multirow[t]{2}{*}{$8 / \mathrm{F}$} & LV3 st & LV2V3st & 3 & 0 \\
\hline & BA oc & BA oc. & & 0 \\
\hline \multirow[t]{3}{*}{$9 / \mathrm{F}$} & LV4 st & LV4st & 7 & + \\
\hline & RV3 st & RV2V3st & & + \\
\hline & & BA oc & & $\begin{array}{l}+ \\
(\mathrm{FMD})\end{array}$ \\
\hline \multirow[t]{2}{*}{$10 / \mathrm{F}$} & LV3 st & LV2V3st & 2 & + \\
\hline & RV4 st & RV4st,fa & & + \\
\hline $11 / \mathrm{M}$ & RV4 oc & RV4oc dl & 10 & 0 \\
\hline \multirow[t]{2}{*}{$12 / \mathrm{F}$} & $\begin{array}{l}\text { LV3st, dl } \\
\text { RV4st }\end{array}$ & LV4 st & 4 & $\begin{array}{l}0 \text { (FMD) } \\
+\end{array}$ \\
\hline & & BA oc & & \\
\hline \multirow[t]{3}{*}{$13 / \mathrm{M}$} & L low & LV4 st & 5 & 0 \\
\hline & & RV4 st & & 0 \\
\hline & & BA oc & & 0 \\
\hline \multirow[t]{3}{*}{$14 / \mathrm{M}$} & LV4 st & LV4 st & 5 & 0 (FMD) \\
\hline & RV4 oc & RV4 oc & & 0 \\
\hline & & BA st & & + \\
\hline $15 / \mathrm{F}$ & RV4 st & RV4 st & 90 & + \\
\hline $16 / F$ & RV4 oc & RV4 st & 3 & + \\
\hline
\end{tabular}

For abbreviations see table 2 .

negative results (28\%) and one false positive result were found giving a $72 \%$ diagnostic sensitivity angiography being the gold standard.

ANGIOGRAPHIC DATA

Five intracranial dissections involved the basilar artery. Vertebral artery dissections were bilateral in four patients. Three patients had a fibromuscular dysplasia and two a moderate $30 \%$ carotid stenosis. Renal arterial angiography never showed a fibromuscular dysplasia, but showed duplicated renal arteries in three patients. There was one false aneurysm. No case of vertebral artery dissection was simultaneously associated with a carotid artery dissection. 


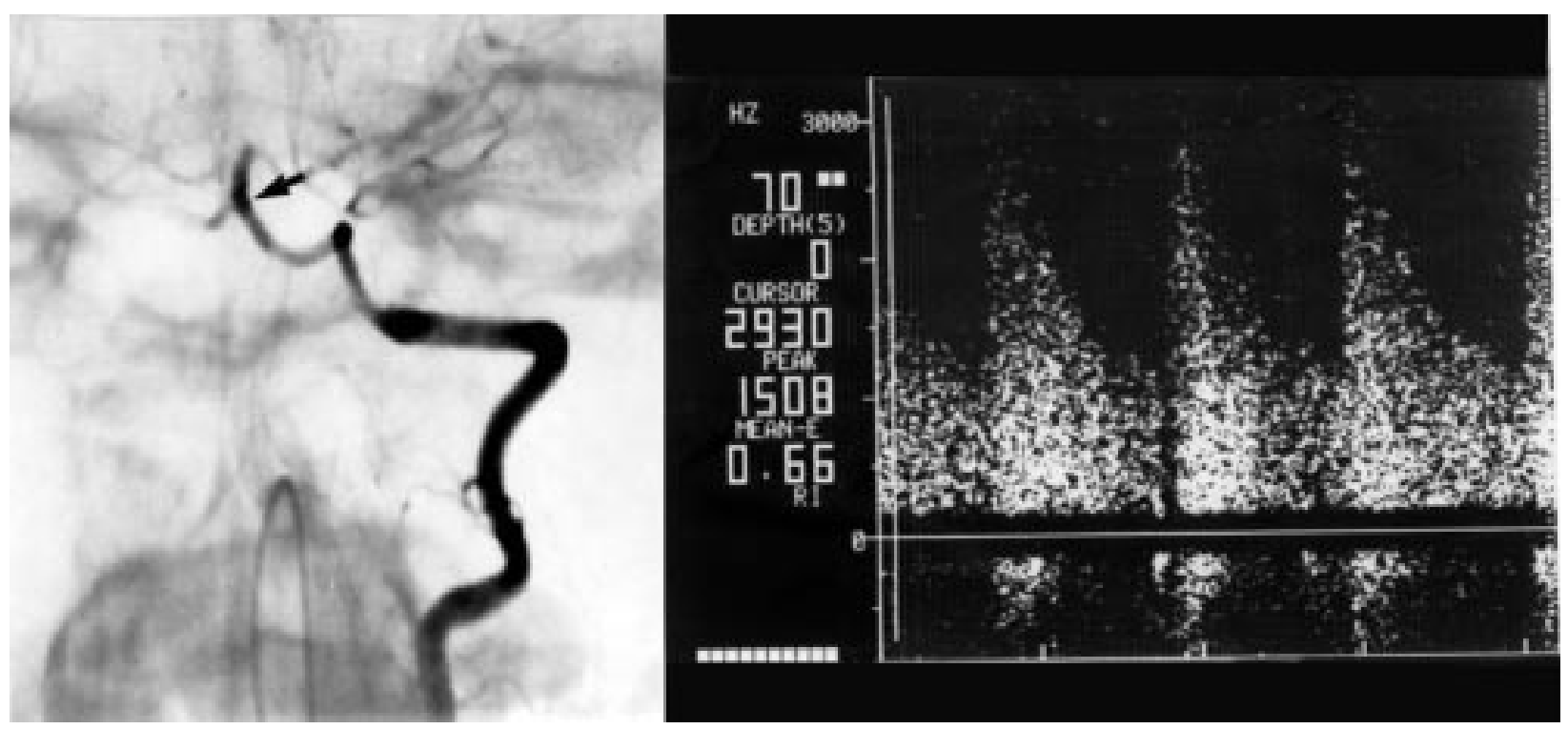

Figure 2 Patient 9: intracranial vertebral artery dissection after neck trauma. Transcranial pulsed Doppler sonography shows no specific sign but segmental acceleration of blood flow velocities with positive and negative frequencies of high energy favours a severe intracranial vertebral artery stenosis. Angiography shows basilar artery occlusion located on the middle segment.

FOLLOW UP AND TREATMENT

Six patients were treated with heparin for three months. This treatment was well tolerated except in one patient who had haematuria. Three patients had no treatment because they were not seen at the acute phase of dissections. The others received antiplatelet drugs.

Ultrasonic investigations have shown a resolution of these dissections in four patients. Taking into account each vessel, haemodynamic resolution was found in $50 \%$ of the patients whereas there was no recurrence of dissection. Two occlusions among six were recanalised.

Significant factors of poor outcome were the initial severity of the stroke $(P=0.03)$ and the bilateral location of dissections $(P=0.04)$. Both occurred more often with intracranial than with extracranial dissections. No correlation could be found with the reopening of the obstructed vessel whatever the site of the dissection.

\section{Discussion}

Both types of vertebral artery dissections occurred with about the same prevalence and our data were in agreement with other series. $^{578}$

Mean age of our patients was slighty less in patients with intracranial (38 years) than in patients with extracranial dissections (40 years). A non-significant female predominance $(53 \%)$ has commonly been found in the extracranial dissection series. ${ }^{5}$ We found $78 \%$ of women in group 2, whereas a large Japanese study ${ }^{11}$ found a male predominance in intracranial dissections $(67 \%)$.

The only established aetiological factors of dissections were fibromuscular dysplasia and head trauma. The $31 \%$ occurrence of fibromuscular dysplasia was similar in our two groups and similar to another series. ${ }^{5}$ Surprisingly, the main surgical series of intracranial vertebral artery dissections ${ }^{811}$ did not men- tion fibromuscular dysplasia. No renal artery dysplasia was identified by angiography in our series including four with fibromuscular dysplasia and only in one patient in another series. ${ }^{4}$ Occurrence of head trauma (44\%) was also similar in both our groups.

Migraine (19\%: exclusively in intracranial vertebral artery dissections) and oral contraceptives $(25 \%)$ did not seem to be implicated in our patients as in all the other series ${ }^{41-24}$ except one. ${ }^{5}$ Vascular risks factors were rare in our study (two in extracranial and four in intracranial dissections). Only one patient had high blood pressure.

Besides young age, two clinical aspects suggested the diagnosis whatever the site of dissection. They had unbearable occipital or lateral neck pain preceding stroke ${ }^{45}$ and progressive onset of cerebral ischaemia within a few hours, whereas the onset is commonly acute in atherothrombotic stroke. Only three patients were free of these two criteria. Isolated and well defined transient ischaemic attacks seemed rare. ${ }^{4578}$ Brainstem strokes were more often associated with intracranial $(78 \%)$ than with extracranial dissections. Wallenberg's syndrome was as rare as cerebellar strokes and represented about $30 \%$ of patients. ${ }^{47}$ Isolated central vertigo lasting several days may be due to a vertebral artery dissection (three patients).

This survey confirms that an anticoagulant treatment has no adverse effect even in intracranial dissections when CT or examination of the CSF does not show bleeding.

Intracranial dissections had a poorer prognosis than extracranial dissections as they gave a permanent disabling deficit in $44 \%$ versus $14 \%$ of the patients. No relation with vessel recanalisation was found in our two groups. The two important factors of poor prognosis were bilateral dissections, more often seen in intracranial than in extracranial dissections, and initial severity of stroke. No recurrence was seen, as reported in previous studies. ${ }^{4} 78$ 
Suggestive colour Doppler signs were rare $(19 \%)$ as most of the dissections were located in the upper part of the vertebral artery. This method could be more fruitful in traumatic dissections. ${ }^{24}$ A segmental dilatation ${ }^{21}$ is a good sign, easier to identify in the proximal part of the vessel than in the V3 segment. It is valid only if an eccentric channel is visualised and if an increased velocity is recorded within the residual channel. Severe haemodynamic abnormalities were identified in $94 \%$ of our population. Only one patient had a normal examination. Vertebral artery occlusions or stenosis were easily identified in the intertranverse segment. As in previous studies, ${ }^{5}{ }^{16}$ we misdiagnosed one dissection which was seen rather late and we failed to detect an anechoic proximal (V1) dissection with an intimal flap located on a deep vertebral artery origin.

Transcranial pulsed Doppler sonography helps to recognise severe intracranial dissections giving a stenosis signal as shown by our seven patients, but the data are not specific and extension to the basilar artery can be difficult to identify particularly when the dissection was bilateral.

The normality of these combined noninvasive investigations at the acute phase of the dissection rules out this aetiology. An initial angiography combined with MRI remains useful as it can show a dysplasia located on other vessels, and detect a false aneurysm or a saccular intracranial aneurysm (3\% in the Mayo Clinic series ${ }^{25}$ ). False aneurysms seemed rarer than commonly described ( from $20 \%$ to $29 \%$ in main studies), but our angiographies were performed early and these lesions often occur later. A reopening of dissections was seen in half of both locations and in up to $76 \%$ in a series of extracranial dissections. ${ }^{4}$ It was rarer in vertebral artery occlusions (30\%). The limitation of our control data by ultrasonic methods is a possible overestimation of the vascular normalisation, but Chiras et $a l^{6}$ have reported a series of control angiography with the same mean percentage of normalisation with control angiographies.

To summarise this survey, brainstem strokes and permanent disabling sequelae were more often associated with intracranial than with extracranial dissections. Importance factors of bad prognosis were the initial severity of the stroke and the bilateral location of dissections. The occurrence of suggestive symptoms (occipital or cervical pain and progressive onset of stroke) was similar in both groups and occurred in a total of $81 \%$ of the patients. Haemodynamic abnormalities detected by ultrasonic data were present in $94 \%$, but characteristic ultrasonic signs were rare $(19 \%)$ and were located only on extracranial vertebral artery dissections. Anticoagulant treatment was well tolerated wherever the dissection's location on the vertebral artery.

We thank J Logello and P Mercier for their help writing this manuscript. 1 Caplan LR, Zarins CK, Hemmati M. Spontaneous dissection of the

2 Hinse P, Thie A, Lachenmayer L. Dissection of the extracranial vertebral artery: report of four cases and review of the literature. F Neurol Neurosurg Psychiatry 1991;54:8639.

3 Hart RG. Vertebral artery dissection. Neurology 1988;38: 987-9.

4 Mokri B, Houser OW, Sandok BA, Piepgras DG. Spontaneous dissection of the vertebral arteries. Neurology 1988;38: $880-5$.

5 Mas JL, Bousser MG, Hasboun D, Laplane D. Extracranial vertebral artery dissections: a review of 13 cases. Stroke 1987;18:1037-47.

6 Chiras S, Marciano S, Molina JV, Touboul J, Poirier B, Bories L. Spontaneous dissecting aneurysm of the extracranial vertebral artery. Neuroradiology $1985 ; 27: 327-$ 33.

7 Sturzenegger M, Heinrich P, Rivoir A, Rihs F, Schmid C. Ultrasound findings in spontaneous extracranial vertebral artery dissection. Stroke 1993;24:1910-21.

8 Halbach VV, Higashida RT, Dowd CF, Frazer W, Smith TP, Teitelbaum P, et al. Endovascular treatment of vertebral artery dissections and pseudoaneurysms. $\mathcal{f}$ Neurosurg 1993;79:183-91.

9 Caplan LR, Baquis GD, Pessin MS, Alton D, Adelman L S, de Witt L D, et al. Dissection of the intracranial vertebral artery. Neurology 1988;38:868-77.

10 Sasaki O, Ogawa H, Koike T, Koizumi T, Tanaka R. A clinicopathological study of dissecting aneurysms of the intracranial vertebral artery. Neurosurgery 1991;75:874-82

11 Yamaura A, Watanabe Y, Saeki N. Dissecting aneurysms of the intracranial vertebral artery. $\mathcal{F}$ Neurosurg $1990 ; 72$ :1838.

12 Maillo A, Diaz P, Morales F. Dissecting aneurysm of the posterior cerebral artery: spontaneous resolution. Neurosurgery 1991;29:291-4.

13 Pozzati E, Padovani R, Fabrizi A, Sabattini L, Gaist G. Benign arterial dissections of the posterior circulation. Neurosurgery 1991;75:69-72.

14 Kitanaka C, Tanaki JI, Kuwahara M, Teraoka A, Sasaki T, Takadura K. Nonsurgical treatment of unruptured intracranial vertebral artery dissection with serial follow-up angiography. F Neurosurg 1994;80:667-74.

15 de Bray JM, Maugin D, Jeanvoine H, Dauzat M, Lhoste P. Etude prospective sur la valeur clinique de l'exploration échotomographique des artères vertébrales. Fournal d'Echographie et de Medicine Ultrasonore 1986;7:80-5.

16 Hoffmann M, Sacco RL, Chan S, Mohr JP. Noninvasive detection of vertebral artery dissection. Stroke 1993;24: 815-9.

17 de Bray JM, Blard JM, TachoT C, Ledemeney M, Davinroy M. Transcranial Doppler ultrasonic examination in vertebro-basilar circulatory pathology. 7 Mal Vasc 1989;14: vertebro-5.

18 Rother J, Wentz KU, Rautenberg W, Schwartz A, Hennerici $M$. Magnetic resonance angiography in vertebro basilar ischemia. Stroke 1993;24:1310-5.

19 Estol CJ, de Witt LD, Tettenborn B. Accuracy of transcranial Doppler in the vertebro basilar circulation [abstract]. Ann Neurol 1990;28:225.

20 Touboul JP, Mas JL, Bousser MG, Laplane D. Duplex scanning in extracranial vertebral artery dissection. Stroke 1988;19:116-21.

21 Hart RG, Easton JD, Dissection of cervical and cerebral arteries. Neurol Clin 1983;1:155-82.

22 Hart RG, Easton JD. Dissections. Stroke 1985;16:925-7.

23 Bille R J, Hingtgen WL, Adams HP, Smoker WRK, Godersky A, Toffol GJ, Cervicocephalic arterial dissections. Arch Neurol 1986;43:1234-8.

24 Bartels E, Flugel KA. Evaluation of extracranial vertebral artery dissection with duplex color flow imaging Stroke 1996;27:290-5

25 Schievink W, Mokri B, Piedgras D, Angiographic frequency of saccular intracranial aneurysms in patients with spontaneous cervical artery dissection. $\mathcal{F}$ Neurosurg 1992;76:62-6. 